${ }^{1}$ Fajar Abdilah, ${ }^{2}$ Linar Humaira, ${ }^{3}$ Anna Fitriani

${ }^{1}$ Konsultan Fajar Berkah Azahra, Villa Ciomas Indah Blok P9, No.18, Bogor, Indonesia.

${ }^{2,3}$ Program Studi Agribisnis, Fakultas Pertanian, Universitas Nusa Bangsa, Jalan K.H. Sholeh Iskandar Km. 4, Tanah Sereal - Kota Bogor 16166, Indonesia.

e-mail: fajarabdilah98@gmail.com e-mail korespondensi: linar.humaira@yahoo.com e-mail: anna.fnoer43@gmail.com

\section{Determinan Produksi Padi Pada Kelompok Tani Rukun Tani di Desa Ciampea Udik Kecamatan Ciampea Kabupaten Bogor}

\author{
(Determination of Rice Production in Rukun \\ Tani Farmers Group in Ciampea Udik Village, \\ Ciampea District, Bogor Regency)
}

ISSN: 2721-8589 (media online) ISSN: 2721-8597 (media cetak)

AGRISINTECH

Journal of Agribusiness and Agrotechnology

Vol. 2, No. 1 (2021)

\begin{abstract}
This study aims to determine the factors that influence rice production in the Rukun Tani Farmer Group, Ciampea Udik Village, Ciampea District, Bogor Regency. This type of research is descriptive quantitative. Data analysis using hypothesis testing and classical assumption test, data processing technique using SPSS version 20 which produces multiple linear regression. The results of segmental determinant analysis, production components, land area, fertilizer costs, pesticide costs, and rice varieties have a significant impact on rice production. The variable that does not have a partial impact on rice production is the labor production factor. Simultaneously the production factors of land area, fertilizer load, pesticide burden, labor, and rice varieties have a significant impact on the rice production of the Rukun Tani Farmer Group in Ciampea Udik Village. Rice production in the Rukun Tani Farmer Group in Ciampea Udik Village was $85.4 \%$ determined by land area, fertilizer load, pesticide load, labor and rice varieties.
\end{abstract}

Keywords: farmer groups, production of rice

\begin{abstract}
ABSTRAK
Penelitian ini memiliki maksud mengetahui faktor-faktor yang mempengaruhi produksi padi di Kelompok Tani Rukun Tani, Desa Ciampea Udik, Kecamatan Ciampea, Kabupaten Bogor. Jenis penelitian adalah deskriptif kuantitatif. Analisis data memakai uji hipotesis dan uji asumsi klasik, teknik pengolahan data menggunakan alat SPSS versi 20 yang menghasilkan regresi linier berganda. Hasil analisis determinan secara segmental, komponen produksi, luas lahan, biaya pupuk, biaya pestisida, dan varietas padi berdampak secara signifikan terhadap produksi padi. Peubah yang tidak berdampak secara parsial terhadap produksi padi yaitu faktor produksi tenaga kerja. Secara simultan faktor produksi luas lahan, beban pupuk, beban pestisida, tenaga kerja, dan varietas padi memberikan dampak secara signifikan terhadap produksi padi Kelompok Tani Rukun Tani di Desa Ciampea Udik. Produksi padi pada Kelompok Tani Rukun Tani di Desa Ciampea Udik sebesar 85,4\% ditentukan oleh luas lahan, beban pupuk, beban pestisida, tenaga kerja dan varietas padi.
\end{abstract}

Kata kunci: kelompok tani, produksi padi 


\section{PENDAHULUAN}

Komoditas beras merupakan bahan kebutuhan pokok dasar warga Indonesia dan memiliki peranan penting dalam perekonomian negara karena sumber pendapatan petani. Semakin bertambah penduduk Indonesia setiap tahun, maka kebutuhan akan pangan juga meningkat. Persoalan prioritas pemerintah Indonesia saat ini adalah kebutuhan masyarakat dengan beras semakin banyak, maka untuk memenuhi kebutuhan dalam negeri harus mendatangkan dari luar negeri (impor). Upaya yang dilakukan untuk mengurangi ketergantungan impor beras salah satunya dengan meningkatkan produksi padi dalam negeri.

Kabupaten Bogor memiliki komoditas pangan unggulan, salah satunya yaitu komoditas padi. Produktivitas padi di Kabupaten Bogor pada tahun 2019 mencapai 62,35 kuintal mengalami peningkatan dari tahun sebelumnya dengan produktivitas sebesar 57,30 kuintal. Hal tersebut menandakan bahwa penggunaan faktor produksi yang efektif dan efisien.

Beberapa hasil penelitian di wilayah yang berbeda seperti di Desa Kanjilo diperoleh bahwa faktor produksi seperti luas lahan, benih, pupuk urea, pupuk ZA, pupuk phonska, tenaga kerja, pengalaman usahatani dan pendidikan, secara bersamasama berpengaruh nyata terhadap produksi padi di desa tersebut (Risna, 2017). Hal senada juga disampaikan oleh Sulferi (2016) yang menyatakan tenaga kerja dan luas lahan berpengaruh positif dan signifikan terhadap produksi padi. Hasil penelitian yang berbeda dari Diantoro dkk (2009) bahwa pupuk, obat-obatan, dan tenaga keja berpengaruh nyata terhadap produksi usahatani padi pada Kelompok Tani Patemon II, sedangkan faktor yang tidak berpengaruh nyata terhadap usahatani padi adalah luas lahan dan benih. Berdasarkan hasil penelitian tersebut, disimpulkan penggunaan faktor produksi yang efektif dan efisien mampu meningkatkan produksi padi di beberapa wilayah desa.

Desa Ciampe Udik Kecamatan Ciampea terletak di Kabupaten Bogor merupakan salah satu daerah penghasil padi. Petani disana telah bergabung menjadi suatu kelompok tani yang dibentuk karena adanya persamaan tujuan dalam berusaha tani padi. Kelompok tani tersebut tentunya menggunakan faktorfaktor produksi yang telah dijelaskan sebelumnya, dan peneliti tertarik untuk memahami faktor apa yang memberikan pengaruh terhadap hasil padi di kelompok tani Rukun Tani di Desa Ciampea Udik, Kecamatan Ciampea, Kabupaten Bogor, dengan begitu petani dapat mengambil keputusan yang tepat terkait upaya peningkatan produksi padi secara efektif dan efisien.

\section{METODE PENELITIAN}

Lokasi penelitian dilakukan secara berkesengajaan (purposive), mengingat Desa Ciampea Udik salah satu pusat hasil padi di Kecamatan Ciampea, Kabupaten Bogor. Masa penelitian kurun waktu enam bulan, mulai bulan keenam atau Juni sampai dengan November 2020.

Populasi penelitian menurut Sudjana (2003) adalah totalitas semua nilai yang mungkin, baik hasil menghitung ataupun pengukuran kualitatif mengenai karakteristik tertentu dari semua anggota kumpulan yang lengkap dan jelas yang ingin dipelajari dari sifat-sifatnya. Populasi dalam penelitian ini adalah seluruh anggota kelompok tani Rukun Tani di Desa Ciampea Udik Kecamatan Ciampea Kabupaten Bogor yang berjumlah sebanyak 36 orang.

Jenis data yang digunakan dalam penelitian data kuantitatif dan kualitatif. Jenis data tersebut digunakan untuk memperolah data angka dan informasi terkait kegiatan kelompok tani Rukun Tani di Desa Ciampea Udik. 
Penelitian data pokok dan sekunder dihimpun melalui pengamatan di lapangan, wawancara dengan kuesioner dari 30 orang petani padi yang tergabung pada Kelompok Tani Rukun Tani yang diambil secara random sampling. Jumlah sampel tersebut diambil berdasarkan pendapat Gay dan Diehl (1992) bahwa penelitian yang dikerjakan merupakan penelitian bersifat korelasi atau berhubungan, maka ukuran sampel sekurang-kurangnya adalah sebesar 30 subjek (unit sampel).

Fakta atau pendukung informasi untuk penelitian, dapat berasal dari Badan Pusat Statistik (BPS) Kabupaten Bogor, serta pemerintah daerah setempat. Penelitian menurut dimensi waktu yaitu data crosssection.

Variabel pada penelitian yaitu sebagai variabel independen adalah luas dari lahan usahatani $\left(\mathrm{X}_{1}\right)$, belanja pupuk $\left(\mathrm{X}_{2}\right)$, belanja pestisida $\left(\mathrm{X}_{3}\right)$, tenaga kerja $\left(\mathrm{X}_{4}\right)$, dan varietas padi $\left(\mathrm{X}_{5}\right)$. Sedangkan variabel dependen (Y) adalah produksi padi.

Penjabaran regresi linier berganda dalam penelitian adalah untuk mengkaji data yang sudah dikumpulkan. Analisis tersebut memiliki tujuan untuk mengetahui determinan produksi antara peubah bebas dengan peubah terikat. Dilanjutkan dengan uji secara simultan maupun parsial.

Berikut rumus perkiraan koefisien regresi menggunakan logaritma alami (Ln) kemudian ditransformasikan ke bentuk linear.

$$
\begin{aligned}
& \operatorname{LnY}=\operatorname{Ln} \alpha+\beta_{1} \operatorname{LnX}_{1}+\beta_{2} \operatorname{LnX}_{2}+\beta_{3} \operatorname{Ln} X_{3}+ \\
& \beta_{4} \operatorname{LnX} X_{4}+\beta_{5} \operatorname{LnX}_{5}+u
\end{aligned}
$$

Keterangan:

$\mathrm{Y}=$ Produksi Padi $(\mathrm{ku})$

$\mathrm{X}_{1}=$ Luas Lahan (ha)

$\mathrm{X}_{2}=$ Biaya Pupuk (Rp)

$\mathrm{X}_{3}=$ Biaya Pestisida (Rp)

$\mathrm{X}_{4}=$ Tenaga Kerja (HOK)

$\mathrm{X}_{5}=$ Varietas padi (Dummy)

$\alpha=$ Intercept $/$ Konstanta

$\beta_{1}=$ Koefisien Regresi Luas Lahan

$\beta_{2}=$ Koefisien Regresi Biaya Pupuk

$\beta_{3}=$ Koefisien Regresi Biaya Pestisida $\beta_{4}=$ Koefisien Regresi Tenaga Kerja

$\beta_{5}=$ Koefisien Regresi Varietas padi

$\mathrm{u}=$ Kesalahan (disturbance term)

$\mathrm{e}=$ logaritma natural

\section{Uji Parsial (Uji t)}

Tes $\mathrm{t}$ statistik menjelaskan seberapa tingkat dampak suatu variabel independen (luas lahan, belanja pupuk, belanja pestisida, tenaga kerja, dan varietas padi) secara individu dalam menjelaskan variasi variabel terikat (produksi). Apabila $t_{\text {hitung }}>t_{\text {tabel }}$ artinya terima hipotesis alternatif yang memberikan makna bahwa suatu variabel terikat dipengaruhi oleh variabel bebas yang bersifat individual (Ghozali, 2001:44). Program yang digunakan untuk pengujian adalah SPSS Versi 20.

\section{Uji Simultan (Uji F)}

Tes statistik $\mathrm{F}$ bertujuan memahami apakah seluruh peubah bebas (luas lahan, beban/biaya pupuk, beban pestisida, tenaga kerja, dan varietas padi) yang masuk dalam model, berpengaruh serentak terhadap produksi padi (variabel terikat). Apabila $\mathrm{F}_{\text {hitung }}>\mathrm{F}_{\text {tabel }}$ maka tolak $\mathrm{H}_{0}$ dan terima Ha. (Ghozali, 2001:44-45). Pengujian hipotesis ini menggunakan program SPSS Versi 20.

\section{Uji Koefisien Determinasi $\left(\mathbf{R}^{\mathbf{2}}\right)$}

Tujuan tes ini adalah menghitung keberhasilan suatu bentuk atau model (goodness of fit) sehingga diperoleh nilai yang memberikan bagian atau persentase variasi total dalam variabel terikat $Y$ yang dijelaskan oleh variabel bebas $\mathrm{X}$ secara bersama (Gujarati, 1995:60).

Nilai koefisien determinasi $\left(\mathrm{R}^{2}\right)$ merupakan nilai antara nol dan satu $\left(0<\mathrm{R}^{2}\right.$ $<1)$. Arti nilai tersebut adalah kalau nilai $\mathrm{R}^{2}$ mengarah ke angka nol, maka kekuatan peubah bebas dalam menerangkan variasi peubah terikat sangat terbatas. Apabila hasil nilai tersebut mengarah ke angka satu, maka peubah bebas memberikan hampir 
seluruh bukti atau data yang dibutuhkan untuk memproyeksi modifikasi peubah terikat (Ghozali, 2001:50).

\section{Uji Asumsi Klasik}

Tujuannya adalah mengetahui pola regresi yang didapatkan apakah menyimpang dari asumsi klasik atau tidak. Uji normalitas residual, uji multikolinearitas, uji heteroskedastisitas, dan uji autokolerasi adalah tes yang digunakan untuk uji asumsi klasik.

\section{HASIL DAN PEMBAHASAN}

Hasil analisis pengaruh/regresi dan uji hipotesis dari data yang dikumpulkan dan dioleh dengan program SPSS Versi 20 dapat dilihat pada Tabel 1 .

Tabel 1. Hasil Analisis Regresi Linear Berganda

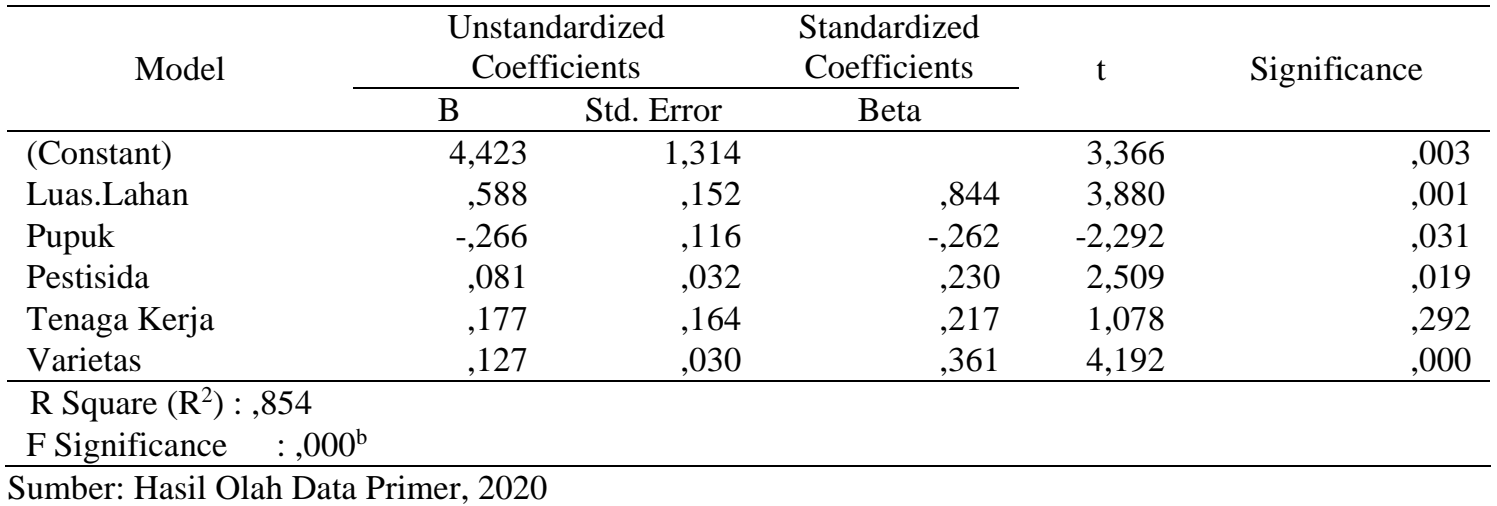

\section{Analisis Regresi Linear berganda}

Berdasarkan Tabel 1, dapat diperhatikan nilai koefisien regresi (B) pada lajur Unstandardized Coefficients, persamaan regresi dapat disusun sebagai berikut.

$$
\begin{aligned}
& \operatorname{LnY}=\operatorname{Ln} 4,423+0,588 \operatorname{LnX}_{1}+(-0,266) \\
& \operatorname{LnX}_{2}+0,081 \operatorname{LnX}_{3}+0,177 \operatorname{LnX}_{4}+ \\
& \quad 0,127 \operatorname{LnX}_{5}+\mathrm{u} \\
& Y=4,423 \mathrm{X}_{1}^{0,588} \quad \mathrm{X}_{2}^{-0,266} \mathrm{X}_{3}^{0,081} \mathrm{X}_{4}^{0,177} \\
& \mathrm{X}_{5}^{0,127} \mathrm{e}^{\mathrm{u}}
\end{aligned}
$$

Berdasarkan persamaan regresi tersebut, maka diterangkan beberapa hal yaitu:

a. Nilai koefisien konstanta $(\alpha)$ sebesar 4,423. Artinya jika variabel luas lahan $\left(\mathrm{X}_{1}\right)$, beban pupuk $\left(\mathrm{X}_{2}\right)$, beban pestisida $\left(\mathrm{X}_{3}\right)$, tenaga kerja $\left(\mathrm{X}_{4}\right)$, dan varietas padi $\left.\mathrm{X}_{5}\right)$ tetap, maka besarnya produksi padi pada kelompok tani Rukun Tani di Desa Ciampea Udik sebesar 4,423 kuintal.

b. Nilai koefisien luas lahan $\left(\mathrm{X}_{1}\right)$ sebesar 0,588 . Bermakna bahwa jika luas lahan meningkat senilai satu persen, sementara nilai beban pupuk, beban pestisida, tenaga kerja, dan varietas padi yang digunakan dianggap tetap maka akan menyebabkan produksi padi pada anggota kelompok tani Rukun Tani di Desa Ciampea Udik meningkat sebesar $0,588 \%$.

c. Nilai koefisien biaya pupuk $\left(\mathrm{X}_{2}\right)$ sebesar -0,266. Artinya jika pengeluaran biaya pupuk meningkat senilai $1 \%$, sedangkan nilai luas lahan, biaya pestisida, tenaga kerja, dan varietas padi yang digunakan dianggap tetap, maka akan menyebabkan penurunan produksi padi pada anggota kelompok tani Rukun Tani di Desa Ciampea Udik sebesar $0,266 \%$.

d. Nilai koefisien biaya pestisida $\left(\mathrm{X}_{3}\right)$ sebesar 0,081. Artinya jika pengeluaran biaya pestisida meningkat senilai 1\%, sedangkan nilai luas lahan, biaya pupuk, tenaga kerja, dan varietas 
padi yang digunakan diasumsikan tetap, akan terjadi kenaikan produksi padi pada anggota kelompok tani Rukun Tani di Desa Ciampea Udik sebesar 0,081\%.

e. Nilai koefisien tenaga kerja $\left(\mathrm{X}_{4}\right)$ senilai 0,177 , berarti apabila penggunaan jumlah tenaga kerja meningkat sebesar $1 \%$, sementara nilai luas lahan, biaya pupuk, biaya pestisida, dan varietas padi yang digunakan dianggap tetap, maka akan terjadi kenaikan hasil padi pada anggota kelompok tani Rukun Tani di Desa Ciampea Udik sebesar 0,177\%.

f. Nilai koefisien varietas padi $\left(\mathrm{X}_{5}\right)$ sebesar 0,127 . Artinya jika penggunaan varietas padi mengalami peningkatan sebesar $1 \%$, sementara nilai luas lahan, beban pupuk, beban pestisida, dan penggunaan tenaga kerja dianggap konstan, akan terjadi penambahan hasil produksi padi pada anggota Kelompok Tani Rukun Tani di Desa Ciampea Udik senilai $0,127 \%$.

\section{Uji Parsial (Uji t)}

Hasil tes secara parsial untuk peubah luas lahan $\left(\mathrm{X}_{1}\right)$ adalah 0,001 , nilai signifikansi $<0,05$, maka terlihat pengaruh positif dan sangat berarti antara luas lahan $\left(\mathrm{X}_{1}\right)$ dengan hasil produksi padi $(\mathrm{Y})$. Uji parsial untuk variabel biaya pupuk $\left(\mathrm{X}_{2}\right)$ didapatkan angka signifikansi yaitu 0,031 , dengan angka signifikansi $<0,05$ maka ada pengaruh negatif dan sangat berarti antara biaya pupuk $\left(\mathrm{X}_{2}\right)$ dengan produksi padi (Y). Hasil tes parsial untuk peubah biaya pestisida $\left(\mathrm{X}_{3}\right)$ diperoleh nilai signifikansi sebesar 0,019, dengan nilai signifikansi $<0,05$, maka terdapat pengaruh positif dan sangat berarti antara biaya pestisida $\left(\mathrm{X}_{3}\right)$ dengan hasil produksi padi (Y). Secara parsial, hasil uji untuk variabel tenaga kerja $\left(X_{4}\right)$ sebesar 0,292, nilai signifikansi $>0,05$, berarti tidak ada pengaruh antara tenaga kerja $\left(\mathrm{X}_{4}\right)$ dengan produksi padi $(\mathrm{Y})$. Hasil uji parsial untuk variabel varietas padi $\left(\mathrm{X}_{5}\right)$ senilai 0,000 , dengan nilai signifikansi $<0,05$ yang artinya ada pengaruh positif antara varietas padi $\left(\mathrm{X}_{5}\right)$ dengan produksi padi (Y).

Kesimpulan yang dapat diambil yaitu bahwa variabel luas lahan $\left(\mathrm{X}_{1}\right)$, variabel biaya pestisida $\left(\mathrm{X}_{3}\right)$, dan variabel varietas padi $\left(\mathrm{X}_{5}\right)$, mempunyai pengaruh positif dan signifikan secara parsial terhadap produksi padi (Y), peubah biaya pupuk $\left(\mathrm{X}_{2}\right)$ mempunyai pengaruh negatif dan signifikan secara parsial terhadap produksi padi (Y), sedangkan variabel tenaga kerja $\left(\mathrm{X}_{4}\right)$ tidak memiliki pengaruh secara parsial terhadap produksi padi (Y) pada kelompok tani Rukun Tani di Desa Ciampe Udik.

\section{Uji Simultan (Uji F)}

Berlandaskan perhitungan regresi merujuk Tabel 1, nilai F signifikan senilai 0,000 , karena nilai probabilitas $<0,05$ yang berarti nilai tersebut signifikan. Hal tersebut memiliki makna bahwa ada dampak positif dan bermakna antara variabel luas lahan $\left(\mathrm{X}_{1}\right)$, biaya pupuk $\left(\mathrm{X}_{2}\right)$, biaya pestisida $\left(\mathrm{X}_{3}\right)$, tenaga kerja $\left(\mathrm{X}_{4}\right)$, dan varietas padi $\left(\mathrm{X}_{5}\right)$ secara serentak terhadap produksi padi (Y) pada Kelompok Tani Rukun Tani di Desa Ciampea Udik.

\section{Koefisien Determinasi $\left(\mathbf{R}^{\mathbf{2}}\right)$}

Atas dasar Tabel 1, R Square adalah 0,854 , jelas terlihat bahwa produksi padi (Y) pada Kelompok Tani Rukun Tani di Desa Ciampea Udik dipengaruhi oleh variabel luas lahan $\left(\mathrm{X}_{1}\right)$, biaya pupuk $\left(\mathrm{X}_{2}\right)$, biaya pestisida $\left(\mathrm{X}_{3}\right)$, tenaga kerja $\left(\mathrm{X}_{4}\right)$, dan varietas padi $\left(\mathrm{X}_{5}\right)$ sebesar 85,4 persen, sedangkan sisa senilai 14,6 persen dipengaruhi peubah lain dan belum dijelaskan pada penelitian. Nilai $R^{2}$ senilai 0,854 , atau mendekati angka 1 maka model variabel luas lahan $\left(\mathrm{X}_{1}\right)$, biaya pupuk $\left(\mathrm{X}_{2}\right)$, biaya pestisida $\left(\mathrm{X}_{3}\right)$, tenaga kerja $\left(\mathrm{X}_{4}\right)$, dan varietas padi $\left(\mathrm{X}_{5}\right)$ dalam menjelaskan keragaman variasi produksi padi pada kelompok tani Rukun Tani di Desa Ciampea Udik sangat jelas 
dan model ini dikatakan baik (goodness of fit).

\section{Asumsi Klasik}

Hasil uji asumsi klasik menggunakan program atau software SPSS versi 20 dan diperoleh hasil yang tersaji di Tabel 2 .

Tabel 2. Hasil Analisis Tes Asumsi Klasik

\begin{tabular}{lrrr}
\hline \multirow{2}{*}{ Model } & \multicolumn{2}{c}{ Collinearity Statistics } & Signifi- \\
\cline { 2 - 3 } & $\begin{array}{c}\text { Tole- } \\
\text { rance }\end{array}$ & $\begin{array}{c}\text { Variance } \\
\text { Inflation } \\
\text { Factor }\end{array}$ & \multicolumn{1}{c}{ cance } \\
\hline Luas.Lahan &, 128 & 7,787 &, 127 \\
Pupuk &, 466 & 2,144 &, 267 \\
Pestisida &, 723 & 1,383 &, 517 \\
Tenaga &, 151 & 6,644 &, 192 \\
Kerja &, 819 & 1,220 &, 078 \\
Varietas &
\end{tabular}

Asymp. Sig. (2-tailed) ,527

Durbin-Watson 2,039

Sumber: Hasil Olah Data Primer, 2020

\section{Uji Normalitas Residual}

Model regresi dikatakan baik yaitu jika data terdistribusi normal atau mendekati rata-rata. Upaya menguji informasi tersebut terdistribusi standar atau non normal, maka dilaksankan tes normalitas residual dengan metode Kolmogorov Smirnov. Bilamana angka Unstandardized Residual lebih besar dari 0,05, disimpulkan informasi data dikatakan memiliki distribusi secara standar.

Pada Tabel 2 menjelaskan bahwa nilai Unstandardized Residual sebesar 0,527. Nilai tersebut lebih besar dari 0,05, kesimpulannya adalah data pada peubah penelitian tersebar secara standar.

\section{Uji Multikolinearitas}

Tes ini adalah memahami keterkaitan linier antara beberapa atau semua peubah bebas yang menjelaskan model regresi. Pola regresi yang baik semestinya tidak ada hubungan antara peubah bebas. Multikolinearitas dapat diketahui dari nilai tolerance dan variance inflation factor (VIF), seumpama nilai tolerance $>0,10$ dan nilai $\mathrm{VIF}<10$, maka dinyatakan tidak terjadi gejala multikolinearitas di model regresi. Jika sebaliknya, maka dinyatakan terjadi gejala multikolinearitas di model regresi.

Berdasarkan Tabel 2, dijelaskan bahwa bentuk regresi sudah bebas dari gejala multikolinearitas karena nilai tolerance lebih besar dari 0,10 yaitu peubah luas lahan sebesar 0,128 , biaya pupuk 0,466, biaya pestisida sebesar 0,723 , tenaga kerja sebesar 0,151 , dan varietas padi sebesar 0,819. Nilai VIF semua variabel <10 dimana variabel luas lahan sebesar 7,787, variabel biaya pupuk sebesar 2,144, variabel biaya pestisida sebesar 1,383, variabel tenaga kerja sebesar 6,644, dan variabel varietas padi sebesar 1,220 sehingga dapat ditarik kesimpulan bahwa pada kajian ini, pada pola regresi, tidak ada gejala multikolineariatas.

\section{Uji Heteroskedastisitas}

Tujuan uji ini adalah melihat kejadian bentuk regresi apakah ada perbedaan jenis dari residual satu observasi ke observasi lain. Bentuk regresi yang baik adalah tidak ada gejala heteroskedastisitas. Uji heteroskedastisitas memakai metode Glejser, yaitu nilai mutlak residual diregresikan dengan masing-masing peubah bebas.

Berdasarkan pada Tabel 2, dijabarkan juga bahwa setiap variabel bebas bernilai signifikansi $>0,05$ dimana nilai signifikansi peubah luas lahan sebesar 0,127 , nilai signifikansi peubah ongkos pupuk sebesar 0,267, nilai signifikansi peubah ongkos pestisida sebesar 0,517, nilai signifikansi peubah tenaga kerja sebesar 0,192 dan nilai signifikansi peubah varietas padi sebesar 0,078. Kesimpulan yang dapat ditarik adalah 
bentuk regresi di penelitian ini tiada mengalami gejala heteroskedastisitas.

\section{Uji Autokolerasi}

Fungsi uji ini adalah mendeteksi tersedia atau tidak autokorelasi yaitu dengan memakai uji nilai Durbin Watson (DW test). Jika angka Durbin Watson (DW) ada antara du dan 4-du, maka bentuk regresi tercatat diartikan lepas dari gejala autokorelasi.

Hasil uji autokorelasi didapatkan angka Durbin Waston sebesar 2,039. Berdasarkan Durbin Watson test, nilai DW yang didapat terletak pada du $<$ DW $<4-$ du atau $1,833<$ $2,039<2,167$, artinya tidak terbentuk autokorelasi pada model regresi sehingga uji autokorelasi terpenuhi.

\section{Pengaruh Luas Lahan Terhadap Produksi Padi}

Peubah luas lahan mempunyai angka signifikansi $0,001<0,05$ artinya luas lahan secara relevan berdampak terhadap kuantitas produksi padi pada Kelompok Tani Rukun Tani di Desa Ciampea Udik. Nilai koefisien regresi variabel luas lahan memiliki nilai 0,588 , berarti setiap $1 \%$ kenaikan luas lahan akan menambah padi sebesar 0,588\% dengan anggapan peubah belanja pupuk $\left(\mathrm{X}_{2}\right)$, belanja pestisida $\left(\mathrm{X}_{3}\right)$, tenaga kerja $\left(\mathrm{X}_{4}\right)$, dan varietas padi $\left(\mathrm{X}_{5}\right)$ konstan/tetap.

\section{Dampak Biaya Pupuk Terhadap Produksi Padi}

Peubah belanja pupuk mempunyai angka signifikansi $0,031<0,05$ artinya biaya pupuk secara signifikan berpengaruh terhadap jumlah produksi padi pada kelompok tani Rukun Tani di Desa Ciampea Udik. Nilai koefisien regresi variabel biaya pupuk bernilai senilai 0,266, berarti jika belanja pupuk naik senilai $1 \%$, akan membuat turun kuantitas produksi padi senilai $0,266 \%$ dengan perkiraan peubah luas lahan $\left(\mathrm{X}_{1}\right)$, belanja pestisida $\left(\mathrm{X}_{3}\right)$, tenaga kerja $\left(\mathrm{X}_{4}\right)$, dan varietas padi $\left(\mathrm{X}_{5}\right)$ konstan/tetap.

\section{Pengaruh Biaya Pestisida Terhadap Produksi Padi}

Peubah belanja pestisida memiliki nilai signifikansi $0,019<0,05$ artinya biaya pestisida berpengaruh signifikan terhadap jumlah produksi padi pada kelompok tani Rukun Tani di Desa Ciampea Udik. Nilai koefisien regresi variabel biaya pestisida memiliki nilai positif senilai 0,081 , berarti kenaikan biaya pupuk senilai $1 \%$ akan menambah kuantitas produksi padi senilai $0,081 \%$, dengan dugaan peubah luas lahan $\left(\mathrm{X}_{1}\right)$, biaya pupuk $\left(\mathrm{X}_{2}\right)$, tenaga kerja $\left(\mathrm{X}_{4}\right)$, dan varietas padi $\left(\mathrm{X}_{5}\right)$ konstan/tetap.

\section{Pengaruh Tenaga Kerja Terhadap Produksi Padi}

Peubah tenaga kerja bernilai signifikansi 0,292>0,05, artinya tenaga kerja secara signifikan tidak berdampak nyata dengan kuantitas produksi padi pada kelompok tani Rukun Tani di Desa Ciampea Udik.

\section{Pengaruh Varietas Padi Terhadap Produksi Padi}

Variabel varietas padi mempunyai nilai signifikansi $0,000<0,05$, artinya varietas padi secara relevan berpengaruh nyata terhadap jumlah produksi padi pada kelompok tani Rukun Tani di Desa Ciampea Udik. Nilai koefisien regresi peubah varietas padi bernilai positif sebesar 0,127, angka tersebut berarti setiap ada kenaikan varietas padi senilai 1 persen, menambah jumlah produksi padi senilai $0,127 \%$ dengan dugaan variabel luas lahan $\left(\mathrm{X}_{1}\right)$, beban/biaya pupuk $\left(\mathrm{X}_{2}\right)$, biaya/beban pestisida $\left(\mathrm{X}_{3}\right)$, dan tenaga kerja $\left(\mathrm{X}_{4}\right)$ konstan/tetap.

\section{SIMPULAN}

Secara segmental komponen produksi luas lahan, biaya pupuk, biaya pestisida, 
dan varietas padi berdampak secara signifikan terhadap produksi padi, peubah yang tidak berdampak secara parsial terhadap produksi padi yaitu faktor produksi tenaga kerja.

Secara simultan faktor produksi luas lahan, beban pupuk, beban pestisida, tenaga kerja, dan varietas padi memberikan dampak secara signifikan terhadap produksi padi Kelompok Tani Rukun Tani di Desa Ciampea Udik. Produksi padi pada Kelompok Tani Rukun Tani di Desa Ciampea Udik sebesar $85,4 \%$ ditentukan oleh luas lahan, beban pupuk, beban pestisida, tenaga kerja dan varietas padi.

\section{DAFTAR PUSTAKA}

Diantoro, K., Sunarsih, M., \& Soejono, D. (2009). Faktor-Faktor Yang Mempengaruhi Produksi Padi Pada Kelompok Tani Patemon II Di Desa Patemon Kecamatan Tlogosari Kabupaten Bondowoso. JSEP (Journal of Social and Agricultural Economics) 3(3), 55-59.

Gay, L.R. dan Diehl, P.L. (1992), Research Methods for Business and. Management. New York: MacMillan Publishing Company.

Ghozali I. (2001). Aplikasi Analisis Multivariate dengan Program SPSS. Semarang: Universitas Diponegoro.

Gujarati, Damodar. (1995). Ekonometrika Dasar. Alih Bahasa Sumarno Zain. Jakarta: Erlangga.

Risna. (2017). Determinan Produksi Padi Sawah Di Desa Kanjilo Kecamatan Barombong Kabupaten Gowa (Skripsi). Makassar: Program Studi Agribisnis, Fakultas Pertanian, Universitas Muhammadiyah Makassar.
Sudjana. (2003). Metoda Statistika. Bandung: Tarsito.

Sugiono. (2014). Metode Penelitian Kuantitatif dan Kualitatif. Bandung: CV. Alfabeta.

Sulferi. (2016). Analisis Faktor-Faktor yang Memengaruhi Produksi Padi di Kabupaten Soppeng (Skripsi). Makassar: Jurusan Ilmu Ekonomi Fakultas Ekonomi Dan Bisnis Islam Universitas Islam Negeri Alauddin Makassar. 